\title{
Prey choice, provisioning behaviour, and effects of early nutrition on nestling phenotype of titmice ${ }^{1}$
}

\author{
Vicente GARCÍA-NAVAS², Esperanza S. FERRER \& Juan José SANZ, Área de Zoología, \\ Departamento de Ciencias Ambientales, Facultad de Ciencias Ambientales y Bioquímica, \\ Universidad de Castilla-La Mancha, Avenida Carlos III s/n E-45071 Toledo, Spain, \\ e-mail: vicente.garcianavas@gmail.com
}

\begin{abstract}
It is generally assumed that blue and great tits (Cyanistes caeruleus, Parus major) compete for the same type of food (Lepidoptera larvae) during the breeding season and that the former have some advantage because they are usually earlier and can exploit small caterpillars that are often more abundant and are not consumed by great tits. However, it is not clear whether, when confronted with similar circumstances (e.g., nestling demand), blue and great tits show similar preferences for a particular caterpillar type. In this 2-y study, we compare the diet of both tit species in detail by controlling for hatching date and brood size. We also examine how the contribution of caterpillars and spiders to the diet is related to nestling development. A positive relationship was found between the percentage of spiders in the diet and nestling tarsus length in both species, reinforcing the idea that neonatal nutrition could have a strong influence on nestling phenotype (e.g., offspring size). Such a correlation may arise because spiders contain a high level of taurine, an essential nutrient in the early development of young, and/or this prey type contains more calcium than other food items, which may affect the rate of nestling bone mineralization. Blue tits fed their young double the number of tortricid larvae in comparison with great tits, whereas the latter showed a clear preference for noctuids and exploited, with a low frequency, a type of larvae not consumed by blue tits, hairy caterpillars (Lasiocampidae). Our results point to resource partitioning by these species in this forest ecosystem and contribute to a better understanding of feeding ecology of titmice, which is particularly timely in a global warming context.
\end{abstract}

Keywords: early nutrition, Lepidoptera, nestling diet, nestling phenotype, Paridae, provisioning behaviour.

Résumé: Il est généralement admis que les mésanges bleues (Cyanistes caeruleus) et les mésanges charbonnières (Parus major) se font compétition pour le même type de nourriture (larves de lépidoptères) durant la période de reproduction. Il est également admis que les mésanges bleues possèdent un certain avantage, car elles se reproduisent plus tôt et mangent de petites chenilles souvent plus abondantes qui ne sont pas consommées par les mésanges charbonnières. Cependant, il n'est pas clair si dans les mêmes conditions (ex. de demande en nourriture des oisillons), les mésanges bleues et charbonnières préfèrent les mêmes types de chenilles. Dans cette étude de 2 ans, nous avons comparé en détail les régimes alimentaires des 2 espèces de mésanges en contrôlant pour la date de ponte et la taille de la couvée. Nous avons aussi examiné si les contributions des chenilles et des araignées au régime alimentaire étaient reliées au développement des oisillons. Chez les 2 espèces, une relation positive a été trouvée entre le pourcentage d'araignées dans le régime alimentaire et la longueur du tarse des oisillons renforçant ainsi l'idée que la nutrition néonatale peut avoir une grande influence sur le phénotype des oisillons (ex. la taille des jeunes). Une telle corrélation peut résulter du fait que les araignées ont un taux élevé de taurine, un nutriment essentiel au développement précoce des jeunes, et/ou que ce type de proie contient plus de calcium que d'autres aliments ce qui peut influencer le taux de minéralisation des os chez les oisillons. Les mésanges bleues ont nourri leurs jeunes avec deux fois plus de larves de tortricidés que les mésanges charbonnières qui elles ont montré une nette préférence pour les noctuidés. Ces dernières ont aussi consommé, quoique peu fréquemment, des livrées (Lasiocampidae), un type de larves boudé par les mésanges bleues. Nos résultats pointent vers une division des ressources entre ces espèces dans cet écosystème forestier et contribuent à une meilleure compréhension de l'écologie alimentaire des mésanges ce qui est particulièrement utile dans un contexte de réchauffement climatique.

Mots-clés: comportement d'approvisionnement, Lepidoptera, nutrition néonatale, Paridae, phénotype des oisillons, régime alimentaire des oisillons.

Nomenclature: Tutin et al., 1993; Dickinson, 2003.

\section{Introduction}

Lepidoptera larvae constitute the main food source for most small insectivorous birds, such as tits (Paridae; see, e.g., Cholewa \& Wesołowski, 2011). They must time their reproduction to match the time of maximum food requirements (chicks 9-10-d-old; Keller \& van Noordwijk, 1994)

${ }^{1}$ Rec. 2012-05-07; acc. 2012-09-12.

Associate Editor: Louis Imbeau.

${ }^{2}$ Author for correspondence.

DOI 10.2980/20-1-3545 with the peak in food availability, that is, when caterpillars have reached their final instars and have not yet begun to crawl to the ground to pupate. Pairs that breed too early or too late relative to the period of maximum caterpillar abundance can suffer a shortage in food supply relative to demand that compromises their breeding performance and fitness (e.g., Perrins, 1991). Regarding this, there is growing attention to the role of local weather conditions (e.g., changes in pre-breeding temperatures) in determining the degree of synchrony between the 2 trophic levels, 
herbivorous insects and insectivorous birds (for a review, see Both, 2010). Much of the work on this topic has focused on the level of mismatch between the chick rearing phase and the food peak (this measure, i.e., degree of synchrony, is used as a yardstick for interpretation of shifts in avian phenology; see Visser \& Both, 2005). However, in addition to the timing of peak food availability, the width and height of the food peak (i.e., the amplitude of this period and the level of food supply) and its composition may also influence the response of birds to phenological changes in their food. With regard to composition, there is little information about bird preferences for particular lepidopteran species and how food (type of prey) influences nestling condition in wild populations (Eeva, Sillanpää \& Salminen, 2009). Only a few studies have looked for an association between the proportion of caterpillars in the diet and nestling mass. Some authors have reported that the 2 variables are quadratically related (García-Navas \& Sanz, 2011; this study), whereas others have found that such a relationship is asymptotic (Tremblay et al., 2005; Burger et al., 2012). Spiders are also an important food for many forest passerines (Gajdoš \& Krištín, 1997); however, there is little information on their influence on nestling phenotype (Arnold et al., 2007). In general terms, studies dealing with nestling diet and provisioning behaviour from an ecological perspective are scarce (see, e.g., Cowie \& Hinsley, 1988; Grundel, 1990; Grundel \& Dahlsten, 1991; Naef-Daenzer, Naef-Daenzer \& Nager, 2000; Mägi et al., 2009, Burger et al., 2012 for exceptions). Roughly, we can divide the work done to date into 1) early descriptive studies (e.g., Gibb \& Betts, 1963; Eguchi, 1980) in which very detailed information on feeding habits during the breeding season is given, but in most cases with relatively small sample sizes and without statistical treatments, and 2) more recent studies in which nestling diet is not examined in detail. For instance, all lepidopteran species are lumped into a single broad category (percentage of caterpillars; e.g., Blondel et al., 1991; Nour et al., 1998; Przybylo \& Merilä, 2000; Tremblay et al., 2005; Massa et al., 2004). In the context of climate change, more detailed studies are necessary that address the effects of birds' preferences for some prey types (i.e., prey choice decisions) on the ability of different but similar species to cope with phenological changes in the underlying tropic levels (by, e.g., switching to alternative prey; see, e.g., Veen et al., 2010). This should be addressed from the point of view of both parents and offspring.

Blue and great tits (Cyanistes caeruleus, Parus major), the 2 commonest European tit species, coexist continuously in the same preferred habitats. Earlier studies have provided evidence for interspecific competition for food between the 2 species during the reproductive period (Minot, 1981; Török \& Tóth, 1999; Dhondt, 2010). Prior to the breeding season the 2 species tend to forage in different places (microhabitats) and prey on different foods, but by the time they are feeding young their foraging sites and food are very similar (e.g., Betts, 1955; Minot, 1981; Massa et al., 2004). Blue tits have been shown to be better exploitation competitors than great tits (asymmetric competition, see Dhondt, 1977; Török \& Tóth, 1999), but the reasons for this are largely unknown and might lie in their method of getting food (Moreno \& Carrascal, 1993) or in the different types of prey consumed. In line with this latter possibility, Török and colleagues have shown that great tits feed their young larger caterpillars in comparison with blue tits (Török, 1986; Török \& Tóth, 1999). However, it is not clear whether blue tits exploit the earlier instars (smaller caterpillars) of the same species upon which great tits feed or they prefer other species of smaller size. There are no studies in the literature directed at the question of whether blue and great tits show similar preferences in terms of prey choice. The vast majority of studies that compared the feeding ecology of blue and great tits do not provide very exhaustive information on dietary features (Minot, 1981; Török, 1985; 1986; Cowie \& Hinsley, 1988; Massa et al., 2004), and in most of them, important factors such as hatching date (great tits are usually earlier than blue tits, and it is known that nestling diet varies seasonally; Sanz, García-Navas \& Ruiz-Peinado, 2010) and brood size (nestling demand can influence the selectivity of parents when bringing food to the nest, e.g., Wright et al., 1998; Grieco, 2002; GarcíaNavas \& Sanz, 2010) are not controlled.

The essential aim of this study was two-fold. First, we studied the association between nestling phenotype and diet features. Specifically, we tested for the influence of the dietary contribution of Lepidoptera larvae and spiders (the 2 main prey types) on nestling condition and size at the age of $10 \mathrm{~d}$. Second, we tested whether blue and great tits differ in their diet preferences under similar circumstances. To that end, we matched broods of both species by hatching date and controlled the potential effect of nestling demand by ensuring that pairs were confronted with a similar brood size. We also explored a number of aspects related to the provisioning behaviour of these species in this Mediterranean population. In particular, we explored the existence of sex differences in provisioning frequency and prey choice of blue and great tits. Lastly, we evaluated sequence patterns in diet selection by examining the diet for prey runs, with a run being defined as occurrences of a specific prey type in consecutive trips.

\section{Methods}

\section{STUDY AREA AND GENERAL FIELD METHODS}

Our study was carried out in the 2008 and 2010 breeding seasons in Quintos de Mora (Toledo Province, central Spain), a government-owned game reserve. The study site comprises deciduous forests dominated by Pyrenean oak (Quercus pyrenaica). A total of 200 wooden nestboxes $(12 \times 11.5 \times 16.5 \mathrm{~cm})$ spaced at $30-40 \mathrm{~m}$ intervals have been available for hole-nesting birds since 2006. Blue tits and great tits are the most frequent users of nestboxes in our study area (occupation rates from 751 first breeding attempts: $62 \%$ and $26 \%$ for blue tits and great tits, respectively). Nestboxes were monitored intensively during the breeding season (from early April to late June) to obtain basic reproductive parameters. Chicks were individually marked with aluminium rings and weighed (pocket balance, $\pm 0.1 \mathrm{~g}$ ), and their tarsi were measured (digital calliper, $\pm 0.01 \mathrm{~mm}$ ), at the age of $13 \mathrm{~d}$. For a more detailed description of the study area and the field protocols, see García-Navas et al. (2011). 


\section{NESTLING DIET AND PROVISIONING BEHAVIOUR}

Nestling diet and parental provisioning effort were studied by filming the inside of the nests with infrared handy-cams (Sony DCR-SR290E, Sony Corp., Tokyo, Japan) when nestlings were 10-d-old (age at which food demand is highest; Keller \& van Noordwijk, 2004). The video cameras were concealed inside a changeable wooden housing fixed to the back of the nestbox facing the entrance hole in such a way that adults entering were filmed and delivered prey could be identified at family level. To habituate birds to this setup the original nestbox was replaced with the model adapted to the video camera $1 \mathrm{~d}$ prior to filming (day 9 post-hatching). On filming day, we removed the nest from the original nestbox and placed it in the dummy nestbox. Recordings were carried out for $90 \mathrm{~min}$ in the morning, before noon (between 08:30 and 11:30), under good weather conditions. The first $30 \mathrm{~min}$ of each video were not analyzsed to standardize the time parents needed to resume their feeding activity after the disturbances caused by setting the video camera. A total of 101 nests (blue tit 2008: $n=49 ; 2010: n=20$; great tit 2008: $n=16$; 2010: $n=16)$ were videotaped. Recordings were played and analyzed frame-by-frame by one of us (E. S. Ferrer) using the software package Adobe Premiere Elements 7.0. While transcribing the video recordings we noted the sex of the parent to test the existence of gender differences in provisioning behaviour (feeding frequency and type of prey delivered) of both species. For great tits, sex identification was easier because males have a wider breast stripe and a much glossier black crown than females (Cramp \& Perrins, 1993). Sex recognition was much more difficult in blue tits; we discerned between males and females by ringing details (females were fitted with coloured plastic bands when nestlings were 8-d-old) or according to their behaviour (e.g., only females brood the young). We counted the number of feeding events performed by both pair members during the last $60 \mathrm{~min}$ of each video-recording. The number of feeding visits per nestling per hour (hereafter feeding rate) was taken as a surrogate of parental provisioning effort. Food items from a total of 2479 feeding trips were identified and used for analyses of diet selection. Food items were classified into 2 main groups: Lepidoptera larvae (caterpillars) and non-lepidoptera larvae. We further distinguished between caterpillars of the 4 major Lepidoptera families (Tortricidae, Noctuidae, Geometridae, and Lasiocampidae) that are widely represented in our study area (Notario et al., 2007; V. García-Navas, unpubl. data). Only a minor proportion of caterpillars remained unidentified. The second group (non-lepidopteran, i.e., prey other than caterpillars) included spiders (Aranaea), pupae, and diverse food items (including Hemiptera, Hymenoptera, Dermaptera, Orthoptera, moths, cocoons, and non-insect food like vegetable tissue, fungus, grit, and eggshell fragments) that were lumped into a miscellaneous category ("others").

\section{DATA ANALYSES}

We analyzed the differences in the composition of nestling food between blue and great tits and the seasonal variation in nestling diet through generalized linear models (GLMs). The percentage of caterpillars and spiders (the 2 main prey categories) in nestling diet was included as the dependent variable, study year and species identity were used as categorical variables, and laying date was fitted as a continuous variable. We also tested for the influence of the dietary contribution of caterpillars and spiders on nestling tarsus length (used as a proxy for offspring size) and nestling condition (body mass corrected for size). Nestling condition was controlled for sibling competition by including brood size as covariate in the models. Hatching date was also included in the full model to control for seasonal effects. Initially, each model was constructed with all explanatory terms fitted, including first-order interactions and quadratic effects to account for potential non-linear relationships. Non-significant terms were removed from the resulting models in a stepwise fashion.

In our population, blue tits (BT) lay smaller clutches than great tits (GT) (mean \pm SD; BT: $7.54 \pm 0.12$, GT: $8.99 \pm 0.19$; study year: $F_{1,272}=8.85, P<0.01$; species: $F_{1,272}=34.32, P<0.001$; laying date: $F_{1,272}=82.66$, $P<0.001)$, and BT clutches hatch later than GT clutches in some years (2008 BT: $14.07 \pm 0.81, \mathrm{GT}: 7.09 \pm 1.44$; 2010 BT: $26.27 \pm 0.79$, GT: $26.90 \pm 1.24$; study year: $F_{1,281}=207.61, P<0.001$; species: $F_{1,281}=8.18, P<0.01$; study year $\times$ species: $\left.F_{1,281}=11.74, P<0.001\right)$. We paired nests ( $n=24$ dyads) of blue and great tits by hatching date and brood size in order to examine differences in nestling diet between the 2 tit species without the confounding effects of timing of breeding and nestling demand. When more than 1 nest met the requirements (similar hatching date and similar brood size) to be matched with another, we chose the one located at a shorter distance. The mean distance between nest dyads was $292 \mathrm{~m}$. Sampled broods ranged in their hatch date from 11 to $62\left(1=1^{\text {st }}\right.$ April). Comparisons were done by employing non-parametric tests (Wilcoxon paired tests).

In a subsequent step, we tested for differences in prey choice and feeding frequency between males and females in both species by means of a paired comparison $t$-test. Since it was not possible to determine the sex of the feeding parent with sufficient reliability in all cases, some nests (most belonging to blue tits) were excluded, and thus our original sample size was reduced (blue tit: $n=42$; great tit: $n=31$ ). We also examined whether the proportion of most common prey types delivered to nestlings correlated between pair members in both species by means of Pearson correlations.

Finally, we analyzed the tendency of both tit species to bring back certain prey types to the nest in runs. In this study, a run of length 3 , for example, was defined as 3 consecutive feeding trips (performed by the same individual) in which a specific prey type was returned to the nest. We then tested for the relationship between the mean and maximum number of consecutive trips bringing the same prey type back to the nest (runs) and the representation of that prey type in the nestling diet. We performed both linear and polynomial regression analyses, choosing the model (linear or non-linear) that best fitted the data.

Percentages were arcsine square root-transformed to fit a normal distribution. Analyses were performed using the software package Statistica version 6 (StatSoft Inc., Tulsa, Oklahoma, USA). Sample sizes differ for different analyses since not all measures could be obtained for all nests. Mean and SD are given. 


\section{Results}

\section{PREY CHOICE AND ITS EFFECTS ON NESTLING CONDITION}

The percentage of caterpillars in the diet differed between species $\left(F_{1,90}=21.10, P<0.001\right.$; BT: $67.7 \pm 2.06$; GT: $80.3 \pm 2.63)$ and years $\left(F_{1,90}=13.91, P<0.001\right.$; 2008: $68.34 \pm 2.35 ; 2010: 76.57 \pm 2.27)$ and decreased with the progress of the season $\left(F_{1,90}=41.64, P<0.001\right.$, estimate: $-0.78 \pm 0.11)$. There was no relationship between the percentage of caterpillars and nestling size in either species (BT: $F_{1,61}=0.76, P=0.38$; GT: $F_{1,24}=0.76$, $P=0.39)$. Nestling mass of blue tits was quadratically related with the percentage of caterpillars in the diet (brood size: $F_{1,58}=7.80, P<0.01$, estimate: $-0.09 \pm 0.03$; nestling tarsus length: $F_{1,58}=25.65, P<0.001$, estimate: $0.71 \pm 0.14$; \% caterpillars: $F_{1,58}=4.82, P=0.03$, estimate: $0.05 \pm 0.02 ; \%$ caterpillars $^{2}: F_{1,58}=3.98, P=0.049$, estimate: $-2.24 \pm 1.12)$. Nestling mass peaked at mediumhigh percentages $(65-75 \%)$ and then declined. We found no relationship between the occurrence of this prey type in the diet and nestling mass in great tits (brood size: $F_{1,23}=5.49, P=0.03$, estimate: $-0.31 \pm 0.13$; \% caterpillars: $F_{1,23}=0.93, P=0.34$, estimate: $0.02 \pm 0.01$ ).

Blue tits relied more heavily on spiders than great tits did (percentage in diet; $F_{1,92}=7.93, P<0.01$; BT: $6.5 \pm 0.69 ;$ GT: $3.1 \pm 0.76)$. Neither study year $\left(F_{1,91}=1.42, P=0.24\right)$ nor calendar date $\left(F_{1,91}=0.01\right.$, $P=0.90)$ had an effect on the frequency with which this prey type was brought to the nest. A positive relationship was found between the percentage of spiders in the diet and nestling tarsus length in great tits (Figure $1 \mathrm{a} ; F_{1,24}=5.12$, $P=0.03$, estimate: $0.04 \pm 0.02$ ). This relationship was also observed for blue tits, but the effect was less pronounced (Figure $1 \mathrm{~b} ; F_{1,61}=3.58, P=0.06$, estimate: $0.02 \pm 0.01$ ). There was no relationship between the percentage of spiders in the diet and nestling body mass in either species (BT: $F_{1,59}=0.68, P=0.41$; GT: $F_{1,23}=1.18, P=0.29$ ).

Parental body size was not significantly related with the contribution of any of the prey types considered in this study (all $P$ values $>0.1$ for both species).

\section{INTERSPECIFIC COMPARISON}

When we restricted our analyses to those cases in which we were able to compare a blue tit with a great tit nest with a similar hatching date and a similar brood size, we found that there was a higher proportion of caterpillars in the food provided by great tits to nestlings in comparison with blue tits (Table I). Great tits included in the nestling diet a higher percentage of noctuid species, whereas the commonest family in the case of blue tits were tortricids (see Table I). The representation of geometrid species in the great tit's diet was roughly double that of blue tits. Unlike great tits, blue tits did not rely on larvae of Malacosoma neustria (Lasiocampidae; Table I). Blue tits brought on average a higher percentage of spiders to their young than did great tits. No differences in pupae proportion between species were found (Table I).

\section{SEX DIFFERENCES}

Among blue tits, there was no difference between the sexes in prey type, nor was there a gender effect on the number of feeding trips (Table II). For great tits, we found that males tended to bring caterpillars with a higher frequency than females (Table II). Within lepidopteran families, male great tits delivered a higher proportion of lasiocampids, the largest food items found in the nestling diet. Meanwhile, females fed their young with a slightly greater proportion of pupae. There were no sex differences in the rate of food provisioning to the young (Table II).

Within pairs, we found a significant relationship between the percentages of lepidoptera larvae, tortricids, and pupae delivered by males and females in both species (Table III). Only in the case of spiders we did not find significant (or marginally significant) association between the proportions of this prey type delivered to the young by both pair members in either species (Table III).

\section{PATTERNS OF FOOD PROVISIONING}

Tortricids were the prey most likely to be delivered in runs by blue tits. In $33 \%(23 / 69)$ of blue tit nests, we found more than 2 consecutive feeding events consisting of the main prey type (tortricids), whereas the second most common family (noctuids) was observed being brought to the nest consecutively in only $13 \%$ of cases. By contrast, noctuids were exploited recurrently by great tits in most
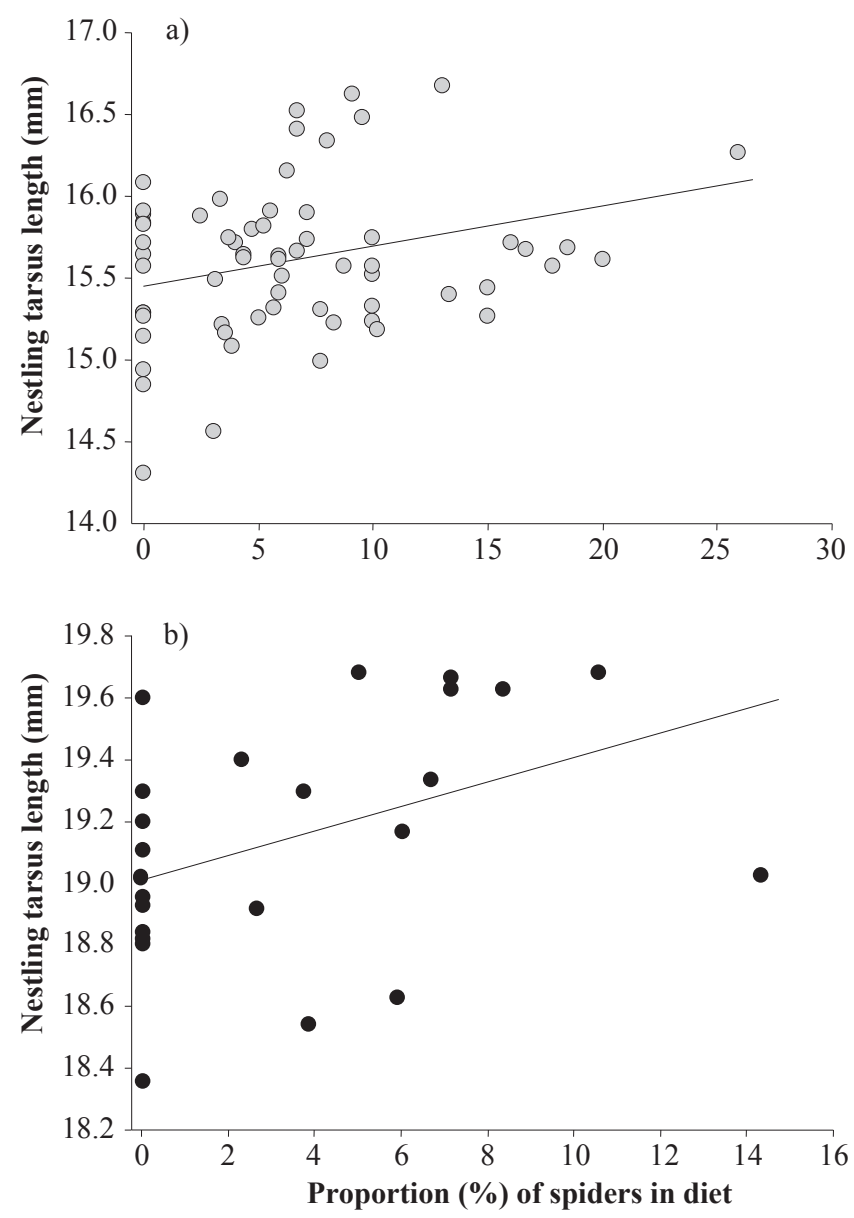

FIGURE 1. Nestling tarsus length of a) great tits and b) blue tits in relation to the proportion of spiders in the diet. Lines were derived from linear regression and are presented for illustrative purposes. 
nests $(79 \%, 22 / 28)$, whereas the occurrence of tortricids on consecutive trips was lower $(18 \%)$. The mean rate per hour at which the most common prey type (tortricids and noctuids for blue tits and great tits, respectively) was delivered did not differ significantly between species $\left(F_{1,74}=0.45\right.$, $P=0.50$; Table IV). There were no interspecific differences in the average value of the longest run registered for each nest $\left(F_{1,74}=0.70, P=0.40\right.$; Table IV $)$. On the other hand, the mean searching time between visits for the run of maximal length observed in each nest (only considering runs with length $>3$ ) was lower in blue tits $\left(F_{1,44}=8.87\right.$, $P<0.01$; Table IV), which suggests that the costs (searching effort) associated with the 2 prey types (tortricids versus noctuids) are likely to be rather different. Neither of the abovementioned variables (mean run length, maximal run

TABLE I. Comparison of the nestling diet of blue tits and great tits from nests paired by hatching date and brood size at Quintos de Mora (Toledo Province, central Spain).

\begin{tabular}{|c|c|c|c|c|}
\hline & $\begin{array}{l}\text { Blue tit } \\
(n=24)\end{array}$ & $\begin{array}{l}\text { Great tit } \\
(n=24)\end{array}$ & $Z$ & $P$-value \\
\hline Date & $51.1 \pm 3.56$ & $51.5 \pm 3.57$ & 0.58 & 0.55 \\
\hline Brood size & $6.8 \pm 1.32$ & $6.9 \pm 1.69$ & 0.95 & 0.34 \\
\hline No. feeding trips & $30.0 \pm 3.27$ & $27.6 \pm 3.45$ & 0.86 & 0.39 \\
\hline Lepidoptera & $67.2 \pm 4.30$ & $80.2 \pm 4.35$ & 2.54 & 0.01 \\
\hline Tortricidae ${ }^{a}$ & $38.9 \pm 4.23$ & $16.3 \pm 4.31$ & 3.31 & $<0.001$ \\
\hline Noctuidae ${ }^{b}$ & $20.1 \pm 3.57$ & $42.3 \pm 4.47$ & 3.80 & $<0.001$ \\
\hline Geometridae $^{c}$ & $6.8 \pm 2.75$ & $12.1 \pm 3.40$ & 1.83 & 0.07 \\
\hline Lasiocampidae $^{\mathrm{d}}$ & - & $6.2 \pm 3.04$ & - & - \\
\hline Undetermined & $1.4 \pm 0.56$ & $3.3 \pm 1.61$ & & \\
\hline Spiders $\mathrm{e}^{\mathrm{e}}$ & $8.3 \pm 2.65$ & $2.8 \pm 1.85$ & 3.09 & $<0.01$ \\
\hline Pupae & $9.5 \pm 4.02$ & $6.4 \pm 2.91$ & 0.88 & 0.37 \\
\hline Others & $15.0 \pm 6.00$ & $10.6 \pm 4.80$ & & \\
\hline No. food items & 722 & 655 & & \\
\hline
\end{tabular}

a Tortricids: The leaf roller Tortrix viridana and Archips xylosteana are the unique tortricoid species that reach high densities in our study area and are well represented in the nestling diet of both species.

b Noctuids: Blue tits preyed on mainly Dryobotodes spp., Orthosia spp. and Dicycla oo whereas great tits fed their young fundamentally with Orthosia incerta, O. stabilis, Noctua interjecta and Dryobota labecula.

c Geometrids: Both tit species preyed on mainly Erannis defoliaria, Colotois pennaria, Alsophila aescularia and Operophtera brumata.

d Lasiocampids: All larvae corresponded to the same species, Malacosoma neustria.

e Spiders: Most of them belonging to the family Theridiidae. length, mean searching time) differed significantly between sexes in either species (all $P$ values $>0.05$ ). However, we found a relationship between the percentage of tortricids in diet and both mean (Figure 2a) and maximal run length of this prey type for each pair member (females, mean run: $r=0.69, P<0.001, n=42$; maximal run: $r=0.67$, $P<0.001, n=42 ; y=2.28+0.08 x+0.002 x^{2}$; males, mean run: $r=0.58, P<0.001, n=35$; maximal run: $r=0.67$, $P<0.001, n=35 ; y=0.70+0.05 x)$. Meanwhile, the proportion of noctuids in the great tits' diet correlated with both mean (Figure 2b) and maximal run length for this prey type in both sexes (females, mean run: $r=0.75, P<0.001$, $n=24$; maximal run: $r=0.73, P<0.001, n=24 ; y=6.92$ $+0.26 x+0.003 x^{2}$; males, mean run: $r=0.44, P=0.03$, $n=24$; maximal run: $r=0.57, P<0.01, n=24 ; y=0.25+$ $0.06 x)$.

\section{Discussion}

We found differences in the nestling diet between blue and great tits when comparing nests with a similar hatch date and a similar brood size. Great tits included a higher proportion of caterpillars in their diet in comparison with the blue tits, which may be explained partly by the fact that the diet breadth of great tits was greater than that of blue tits, the former delivering caterpillars belonging to 4 different lepidopteran families (Noctuidae, Geometridae, Tortricidae, and Lasiocampidae), whereas the latter did not consume lasiocampid larvae (see more below). When exploring the link between diet and nestling development, we found no relationship between nestling size and the proportion of caterpillars provided by the parents in either species. Like García-Navas and Sanz (2011), we found that nestling mass of blue tits was related quadratically with the percentage of caterpillars in the diet, whereas the occurrence of this prey type was not related to nestling mass of great tits. These findings contrast with those of Wilkin, King, and Sheldon (2009), who reported a marginal positive association between nestling mass and the proportion of caterpillars in the diet for a great tit population at Wytham, Oxford. However, in the figure provided by these authors higher fledgling mass values did not correspond to higher proportions of caterpillars; in fact, the relationship may be better fit to an asymptotic function (see Figure $2 \mathrm{~d}$ in Wilkin, King \& Sheldon, 2009). With regard to non-lepidopteran

TABLE II. Intersexual differences in prey choice and provisioning effort (number of feeding trips per nest per hour) of blue tits and great tits. Paired $t$-tests were used.

\begin{tabular}{|c|c|c|c|c|c|c|c|c|}
\hline & \multicolumn{4}{|c|}{ Blue tit } & \multicolumn{4}{|c|}{ Great tit } \\
\hline & $\begin{array}{l}\text { Female } \\
(n=43)\end{array}$ & $\begin{array}{c}\text { Male } \\
(n=43)\end{array}$ & $t$ & $P$-value & $\begin{array}{l}\text { Female } \\
(n=32)\end{array}$ & $\begin{array}{c}\text { Male } \\
(n=32)\end{array}$ & $t$ & $P$-value \\
\hline No. feeding trips & $15.2 \pm 2.72$ & $14.0 \pm 3.05$ & 0.69 & 0.49 & $12.3 \pm 2.93$ & $13.8 \pm 2.85$ & 0.64 & 0.53 \\
\hline Lepidoptera & $64.3 \pm 4.60$ & $66.2 \pm 3.97$ & 0.49 & 0.62 & $65.0 \pm 4.81$ & $74.6 \pm 4.85$ & 1.98 & 0.05 \\
\hline Tortricidae & $35.1 \pm 4.93$ & $33.3 \pm 4.31$ & 1.29 & 0.20 & $12.5 \pm 3.37$ & $10.2 \pm 3.93$ & 0.75 & 0.46 \\
\hline Noctuidae & $17.8 \pm 3.92$ & $22.2 \pm 3.83$ & 0.73 & 0.47 & $43.3 \pm 3.86$ & $45.4 \pm 4.16$ & 0.43 & 0.67 \\
\hline Geometridae & $10.0 \pm 3.72$ & $9.1 \pm 3.56$ & 0.42 & 0.68 & $5.8 \pm 1.42$ & $10.1 \pm 2.91$ & 1.56 & 0.13 \\
\hline Lasiocampidae & - & - & & & $3.3 \pm 1.28$ & $8.2 \pm 2.55$ & 1.99 & 0.05 \\
\hline Undetermined & $1.4 \pm 3.72$ & $1.6 \pm 3.56$ & & & $0.0 \pm 3.72$ & $0.7 \pm 3.56$ & & \\
\hline Spiders & $7.9 \pm 3.37$ & $7.9 \pm 2.92$ & 0.77 & 0.44 & $3.2 \pm 0.99$ & $5.6 \pm 3.32$ & 0.80 & 0.42 \\
\hline Pupae & $9.7 \pm 3.91$ & $8.4 \pm 3.52$ & 0.50 & 0.62 & $13.2 \pm 4.23$ & $5.7 \pm 1.83$ & 1.86 & 0.07 \\
\hline Miscellaneous & $18.1 \pm 3.97$ & $17.5 \pm 3.02$ & & & $18.6 \pm 4.07$ & $14.1 \pm 3.08$ & & \\
\hline
\end{tabular}


prey, in our study we found that blue tits brought more spiders than great tits did, which is in agreement with the findings of Török and Tóth (1999). The importance of spiders to the nestling diet has been acknowledged in several studies (see, e.g., Gajdoš \& Krištín, 1997). A pattern frequently reported is a peak in spider provisioning during early stages of nestling development (5-6-d-old) independent of season and the availability of spiders in the environment (e.g., Cowie \& Hinsley, 1988; Grundel \& Dahlsten, 1991; Radford, 2008; García-Navas, Ferrer \& Sanz, 2012, see also Pagani-Núñez et al., 2012). Royama (1970) postulated that spiders have some special nutritional value important for the growth of nestlings that is not found in other types of food. More recent studies (Ramsay \& Houston, 2003) have shown that spiders are nutritionally similar to caterpillars, except that spiders contain high levels of taurine, an amino acid essential for the proper development and function of the central nervous system (Ramsay \& Houston, 2003; Arnold et al., 2007 and references therein). Taurine is also reported to have effects on personality (e.g., risk-taking behaviour) and cognition in offspring (Arnold et al., 2007). To our knowledge, no studies have shown a direct link between taurine levels and body size in wild birds, despite there being some evidence from poultry that taurine is a growth factor directly associated with bone growth (Martin \& Patrick, 1961). Here, we have shown a positive association between spider provisioning and nestling tarsus length in both tit species, although in the case of blue tits this relationship was marginal $(P=0.06)$. However, this result could also be related to the fact that spiders have a higher calcium content than caterpillars and other arthropods (Graveland \& van Gijzen, 1994), which could positively impact the rate of skeletal mineralization (Tilgar et al., 2005). It should be noted that

TABLE III. Within-pair correlation between the percentages of different prey types delivered by males and females for blue and great tit breeding pairs. Pearson' correlations are shown.

\begin{tabular}{|c|c|c|c|c|c|c|}
\hline & \multicolumn{3}{|c|}{ Blue tit $(n=42)$} & \multicolumn{3}{|c|}{ Great tit $(n=31)$} \\
\hline & $r$ & $t$ & $P$-value & $r$ & $t$ & $P$-value \\
\hline Lepidoptera $^{\mathrm{a}}$ & 0.51 & 3.73 & $<0.001$ & 0.54 & 0.50 & $<0.01$ \\
\hline Tortricids & 0.38 & 2.57 & 0.01 & 0.37 & 2.17 & 0.04 \\
\hline Noctuids & 0.46 & 3.28 & $<0.01$ & 0.33 & 1.86 & 0.07 \\
\hline Geometrids & 0.28 & 1.87 & 0.07 & 0.43 & 2.59 & 0.01 \\
\hline Lasiocampids & - & - & - & 0.21 & 1.14 & 0.26 \\
\hline Spiders & 0.05 & 0.32 & 0.75 & 0.07 & 0.36 & 0.72 \\
\hline Pupae & 0.60 & 4.70 & $<0.001$ & 0.41 & 2.43 & 0.02 \\
\hline
\end{tabular}

a Lepidoptera larvae: Total percentage of this prey type considering all families and undetermined caterpillars.

TABLE IV. Most common prey delivered to their young in runs by blue and great tits, mean and maximal run length and mean searching time between consecutive visits for each prey type (tortricids $v s$ noctuids). Ranges and number of runs are given in parentheses.

\begin{tabular}{llccc}
\hline \hline \multirow{2}{*}{ Species } & \multirow{2}{*}{$\begin{array}{l}\text { Most common } \\
\text { prey type }\end{array}$} & \multicolumn{3}{c}{ Prey runs } \\
\cline { 3 - 5 } & Mean & Max. & Time \\
\hline Blue tit & Tortricidae & 1.8 & 2.8 & $2 \min 41 \mathrm{~s}$ \\
& & $(1.0-5.0)$ & $(1.0-11.0)$ & $(n=33)$ \\
Great tit & Noctuidae & 1.9 & 3.2 & $6 \min 4 \mathrm{~s}$ \\
& & $(1.0-6.0)$ & $(1.0-9.0)$ & $(n=25)$ \\
\hline \hline
\end{tabular}

in our study area calcium-rich food items are scarce, which seems to impair the breeding success of these populations (see García-Navas et al., 2011). Overall, our result reinforces those previously reported in studies with captive birds (Boag, 1987; Searcy, Peters \& Nowicki, 2004; Soma et al., 2006): early nutrition may have a strong effect on nestling phenotype (e.g., body size), which may also have fitness consequences.

With respect to caterpillars, blue tits included a higher percentage of tortricids in the nestling diet in comparison with the great tits, which opted to exploit larger caterpillars (noctuids and to a lesser extent, geometrids) (mean length: tortricids: $18-20 \mathrm{~mm}$, noctuids: $25-30 \mathrm{~mm}$; García-Navas, Ferrer \& Sanz, 2012). The oak leafroller (Tortrix viridana) and Archips xylosteana (Tortricidae) are 2 of the more abundant lepidopteran species in our study area, where they can reach densities causing severe defoliation of oaks (MMA, online; V. García-Navas, pers. obs.). Both species are sedentary and gregarious during the larval stage and do
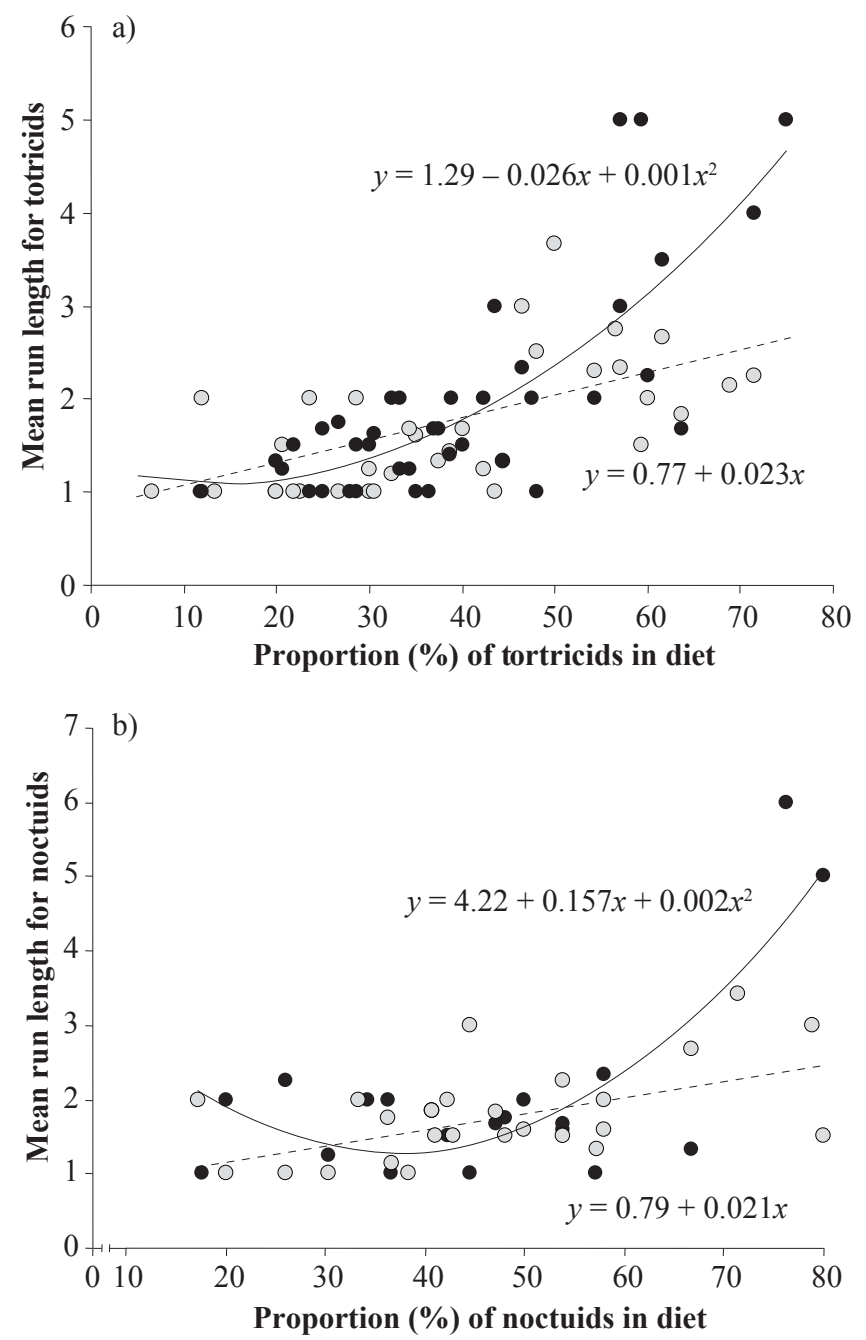

Figure 2. Mean length of runs in which only a) tortricids or b) noctuids were taken to the nest in successive visits plotted against their percentage occurrence in the diet of a) blue tit and b) great tit nestlings, respectively. Black dots and continuous line: delivered by female; grey dots and discontinuous line: delivered by male. 
not leave their host tree to hide or pupate on the ground; they remain in their leaf shelters (which can be used by birds as visual cues; Murakami, 1999) until their emergence as adult moths. The abundance of tortricid larvae, their limited mobility, and their tendency to present a contagious distribution encourage blue tits to perform repeated visits to the same feeding site (long runs, Figure 1a), enabling an increase in the number of foraging visits per unit of time (Naef-Daenzer \& Keller, 1999). The low representation of tortricids in the diet of nestling great tits despite their very easy accessibility indicates that this prey type is not preferred by this species; instead, great tits show an overwhelming preference for noctuids, even though they require longer searching times (see Table III). Noctuids were exploited recurrently by great tits and constituted their most common prey, whereas blue tits seem to increase their selectivity and exploit more time-demanding prey (noctuids) only under optimal conditions (low brood demand: García-Navas \& Sanz, 2010; good synchrony with the food peak: García-Navas \& Sanz, 2011). Thus, the profitability (defined as the amount of the prey in terms of biomass or calorific value that the predator can collect in a given time spent hunting this prey type, sensu Royama, 1970) of noctuids (and tortricids) is probably different for great tits and blue tits, influencing the cost-benefit balance that in turn determines the hierarchy of foraging decisions in each species. Along these lines, we have shown previously that to feed young with one or the other type of caterpillar is not a trivial matter from the point of view of the offspring (García-Navas \& Sanz, 2011). In this sense, recent studies (Arnold et al., 2010; Eeva et al., 2010) have shown that lepidopteran larvae can differ greatly in their concentration of carotenoids (antioxidants such as lutein, zeaxanthin, $\beta$-carotene). On the basis of their appearance and the birds' preference, it is likely that noctuids (caterpillars with a greater amount of tissue) possess a higher caloric content in comparison with tortricid larvae, whose aspect is less consistent (watery guts) and nutritive. Regrettably, there is no information available on the energetic value of different caterpillar types. Further studies on the nutritional profiles of avian diets in the wild are required to better understand how prey quality impinges on parental provisioning strategies and nestling phenotype.

One striking result of this study is that great tits, but not blue tits, consumed hairy caterpillars (Lasiocampidae larvae, but not Lymantridae larvae also present in the study area). Some field studies have documented the use of caterpillars with warning signals (urticant setae, aposematic colouration) by great tits (nun moth [Lymantria monacha]: Betts, 1955; fall webworm [Hyphantria cunea]: Itô \& Miyashita, 1968; lackey moth [Malacosoma neustria]: Royama, 1970; pine processionary moth [Thaumetopoea pityocampa]: e.g., Barbaro \& Battisti, 2010), whereas it is commonly assumed that blue tits avoid hairy caterpillars such as L. dispar or M. neustria (e.g., Dias \& Blondel, 1996). Hairy caterpillars do not occur commonly in the great tit diet, although some species are able to cyclically reach outbreak numbers (e.g., Liebhold et al., 2000). For instance, Pimentel and Nilsson $(2007 ; 2009)$ reported that Portuguese great tits exploited nests containing larvae of
T. pityocampa (Notodontidae) during the winter period when there were no other caterpillar species available. In our case, great tits made use of $M$. neustria with a low frequency and during a brief period (late season), despite this species being abundant, especially in the 2008 breeding season (MMA, online; V. García-Navas, pers. obs.). Since M. neustria can attain high densities in our region (e.g., Soria, 1987), it is likely that great tits opt to exploit this secondary food source under certain conditions (low availability of other lepidopteran species, delayed timing with respect to main prey phenology), whereas blue tits do not profit from this seemingly unattractive resource. Despite this difference, blue tits appear to have some advantage with respect to great tits in our study area because their standard prey (tortricids) is superabundant, and substituting this caterpillar type for another can only be an improvement (that is, to opt for a more epicure menu by increasing the proportion of larger caterpillars such as noctuids; see Table I in García-Navas, Ferrer \& Sanz, 2012). By contrast, great tits, probably due to their larger size, are forced to consume noctuids, and thus inclusion of a large quantity of tortricids in their diet might be considered a last resort. On the other hand, our results should be interpreted with caution; 1 weakness of our study is that because in 1 of the breeding seasons (2008) great tits laid earlier than blue tits, we may have paired high-quality individuals (early-laying blue tits) with individuals that were not among the high-ranked ones (i.e., middle-quality individuals; middle- or late-laying great tits), possibly leading to biases in our results.

Regarding intersexual differences in parental care, we did not find a gender effect on feeding frequency or prey choice in blue tits. Our results contrast with those of Bańbura et al. (2001), who found that males in a Corsican blue tit population brought a higher proportion of caterpillars than females, probably due to the latter spending more time at the nest undertaking sanitation activities (e.g., grooming) in response to high external parasitism, which may have led them to be less selective (see also HurtrezBoussès et al., 1998). In our study area, birds are exposed to a low ectoparasite load (mites, flies, and blowflies are relatively less abundant) in comparison with northern populations (V. García-Navas \& J. J. Sanz, unpubl. data). As a consequence, female blue tits are likely to be less time-constrained, spending less time at the nest, and as a result the time budgets of both pair members and thus their selectivity in prey choice are probably very similar (García-Navas \& Sanz, 2010). With respect to great tits, males supplied chicks with a higher proportion of caterpillars in comparison with females. This result can be explained in part by the higher frequency with which male great tits preyed on lasiocampids. The fact that females were more reluctant to exploit this prey type may be linked to personality traits (aggressive behaviour, risk-taking, explorative behaviour, and others), which often differ between sexes (males are more bold and aggressive than females) and may affect birds' reaction to aposematic prey such as Malacosoma neustria larvae (Exnerová et al., 2007). Regarding the effect of parental size on prey choice, we did not find any association between the body size of adults and their diet preferences 
in either species. Thus, our results do not support the existence of the link between parental morphological traits and food selection predicted by the sexual size dimorphism hypothesis (e.g., Gosler, 1987), for which there is only very weak evidence (Przybylo, 1995; Przybylo \& Merilä, 2000; Blondel et al., 2002). To the contrary, we found a significant association between the proportions of most common prey types (except spiders) delivered to chicks by both pair members in both species. This may be explainable by the fact that males and females within the same pair are confronted by similar situations (nestling demand) when determining their food preferences (target prey type) and by the fact that they forage in the same territory and thus are faced with similar opportunities when feeding their young (i.e., the same "set meal").

To conclude, our study suggests that blue and great tits show different levels of specialization in exploiting Lepidoptera larvae in this forest ecosystem. A better understanding of nestling diet (prey preferences) is crucial to test adaptive hypotheses on the breeding seasons of hole-nesting passerines (see Cholewa \& Wesołowski, 2011). We believe that this type of basic information is needed before we can answer more sophisticated questions, such as, would global warming lead to diet shifts in these species (Both, 2010)? Lastly, as in previous studies (Arnold et al., 2007), the relationship between spider intake and nestling size shown here highlights the importance of considering not only the composition of nestling food, but also the quality of the diet (its nutritional value) and the influence of this factor on offspring growth and development.

\section{Acknowledgements}

We are grateful to C. R. Vigal (Centro Quintos de Mora) for the facilities offered to us to research in this restricted area. L. Imbeau and three anonymous referees provided comments that improved an earlier version of this paper. V. García-Navas was supported by a FPI predoctoral fellowship (Spanish Ministry of Science and Innovation (MICINN)-European Social Fund). This study was financed by the MICINN (grant reference: GCL2007-61395).

\section{Literature cited}

Arnold, K. E., S. L. Ramsay, C. Donaldson \& A. Adam, 2007. Parental prey selection affects risk-taking behaviour and spatial learning in avian offspring. Proceedings of the Royal Society of London B, 274: 2563-2569.

Arnold, K. E., S. L. Ramsay, L. Henderson \& S. D. Larcombe, 2010. Seasonal variation in diet quality: Antioxidants, invertebrates and blue tits Cyanistes caeruleus. Biological Journal of the Linnean Society, 99: 708-717.

Bańbura, J., P. Perret, J. Blondel, A. Sauvages, M.-J. Galan \& M. M. Lambrechts, 2001. Sex differences in parental care in a Corsican blue tit Parus caeruleus population. Ardea, 89: 517-526.

Barbaro, L. \& A. Battisti, 2011. Birds as predators of the pine processionary moth (Lepidoptera: Notodontidae). Biological Control, 56: 107-114.

Betts, M. M., 1955. The food of titmice in oak woodland. Journal of Animal Ecology, 24: 282-323.
Blondel, J., A. Dervieux, M. Maistre \& P. Perret, 1991. Feeding ecology and life history variation of Blue Tit in Mediterranean deciduous and sclerophyllous habitats. Oecologia, 88: 9-14.

Blondel, J., P. Perret, M.-C. Anstett \& C. Thébaud, 2002. Evolution of sexual size dimorphism in birds: Test of hypotheses using blue tits in contrasted Mediterranean habitats. Journal of Evolutionary Biology, 15: 440-450.

Boag, P. T., 1987. Effects of nestling diet on growth and adult size of zebra finches (Poephila guttata). Auk, 104: 155-166.

Both, C., 2010. Food availability, mistiming and climate change. Pages 129-147 in A. P. Møller, W. Fiedler \& P. Berthold (eds). Effects of Climate Change on Birds. Oxford University Press, Oxford.

Burger, C., E. Belskii, T. Eeva, T. Laaksonen, M. Mägi, R. Mänd, A. Qvarnström, T. Slagsvold, T. Veen, M. E. Visser, K. L. Wiebe, C. Wiley, J. Wright \& C. Both, 2012. Climate change, breeding date and nestling diet: How temperature differentially affects seasonal changes in pied flycatcher diet depending on habitat variation. Journal of Animal Ecology, 81: 926-936.

Cholewa, M. \& T. Wesołowski, 2011. Nestling food of European hole-nesting passerines: Do we know enough to test the adaptive hypotheses on breeding seasons? Acta Ornithologica, 46: $105-116$.

Cowie, R. J. \& S. A. Hinsley, 1988. Feeding ecology of great tits (Parus major) and blue tits (Parus caeruleus) breeding in suburban gardens. Journal of Animal Ecology, 57: 611-626.

Cramp, S. \& C. M. Perrins, 1993. The Birds of the Western Palearctic. Optimedia, Oxford.

Dhondt, A. A., 1977. Interspecific competition between great and blue tit. Nature, 268: 521-523.

Dhondt, A. A., 2010. Effects of competition on great and blue tit reproduction: Intensity and importance in relation to habitat quality. Journal of Animal Ecology, 79: 257-265.

Dias, P. C. \& J. Blondel, 1996. Breeding time, food supply and fitness components of blue tits Parus caeruleus in Mediterranean habitats. Ibis, 138: 644-649.

Dickinson, E. C. (ed.), 2003. The Howard and Moore Complete Checklist of the Birds of the World. $3^{\text {rd }}$ Edition. Princeton University Press. Princeton, New Jersey.

Eeva, T., S. Sillanpää \& J.-P. Salminen, 2009. The effects of diet quality and quantity on plumage colour and growth of great tit nestlings: A food manipulation experiment along a pollution gradient. Journal of Avian Biology, 40: 1-9.

Eeva, T., S. Helle, J.-H. Salminen \& H. Hakkarainen, 2010. Carotenoid composition of invertebrates consumed by two insectivorous bird species. Journal of Chemical Ecology, 36: 608-613.

Eguchi, K., 1980. The feeding ecology of the nestling great tit, Parus major minor, in the temperate ever-green broadleaved forest II. With reference to breeding ecology. Researches on Population Ecology, 22: 284-300.

Exnerová, A., P. Štys, E. Fučíková, S. Vesela, K. Svádová, M. Prokopová, V. Jaroŝík, R. Fuchs \& E. Landová, 2007. Avoidance of aposematic prey in European tits (Paridae): Learned or innate? Behavioral Ecology, 18: 148-156.

Gajdoš, P. \& A. Krištín, 1997. Spiders (Araneae) as bird food. Proceedings of the $16^{\text {th }}$ European Colloquium of Arachnology: 91-105.

García-Navas, V., E. S. Ferrer \& J. J. Sanz, 2012. Prey selectivity and parental feeding rates of Blue Tits Cyanistes caeruleus in relation to nestling age. Bird Study, 59: 236-242.

García-Navas, V. \& J. J. Sanz, 2010. Flexibility in the foraging behaviour of blue tits in response to short-term manipulations of brood size. Ethology, 116: 744-754. 
García-Navas, V. \& J. J. Sanz, 2011. The importance of a main dish: Nestling diet and foraging behaviour in Mediterranean blue tits in relation to prey phenology. Oecologia, 165: 639-649.

García-Navas, V., J. J. Sanz, S. Merino, J. Martínez-de la Puente, E. Lobato, S. del Cerro, J. Rivero, R. Ruiz de Castañeda \& J. Moreno, 2011. Experimental evidence for the role of calcium in eggshell pigmentation pattern and breeding performance in blue tits Cyanistes caeruleus. Journal of Ornithology, 152: 71-82.

Gibb, J. A. \& M. M. Betts, 1963. Food and food supply of nestling tits in Breckland Pine. Journal of Animal Ecology, 32: 489-533.

Gosler, A. G., 1987. Sexual dimorphism in the summer bill length of the great tit. Ardea, 75: 91-98.

Graveland, J. \& T. van Gijzen, 1994. Arthropods and seeds are not sufficient as calcium sources for shell formation and skeletal growth in passerines. Ardea, 82: 299-314.

Grieco, F., 2002. Time constraint on food choice in provisioning blue tits, Parus caeruleus: The relationship between feeding rate and prey size. Animal Behaviour, 64: 517-526.

Grundel, R., 1990. The role of dietary diversity, prey capture sequence and individuality in prey selection by parent mountain chickadees Parus gambeli. Journal of Animal Ecology, 59: 959-976.

Grundel, R. \& D. L. Dahlsten, 1991. The feeding ecology of mountain chickadees (Parus gambeli): Patterns of arthropod prey delivery to nestling birds. Canadian Journal of Zoology, 69: $1793-1804$.

Hurtrez-Boussès, S., J. Blondel, P. Perret, J. Fabreguettes \& F. Renaud, 1998. Chick parasitism by blowflies affects feeding rates in a Mediterranean population of blue tits. Ecology Letters, 1: 17-20.

Itô, Y. \& K. Miyashita, 1968. Biology of Hyphantria cunea Drury (Lepidoptera: Arctiidae) in Japan. V. Preliminary life tables and mortality data in urban areas. Researches on Population Ecology, 10: 177-209.

Keller, L. F. \& A. J. van Noordwijk, 1994. Effects of local environmental conditions on nestling growth in the great tit (Parus major L.). Ardea, 82: 349-362.

Liebhold, A., J. Elkinton, D. Williams \& R.-M. Muzika, 2000. What causes outbreaks of the gypsy moth in North America? Population Ecology, 42: 257-266.

Mägi, M., R. Mänd, H. Tamm, E. Sisask, P. Kilgas \& V. Tilgar, 2009. Low reproductive success of great tits in the preferred habitat: A role of food availability. Écoscience, 16: 145-157.

Martin, W. G. \& H. Patrick, 1961. The effect of taurine on the Sulphate-S35 retention by chicks. Poultry Science, 40: 267.

MMA. Red Europea de Seguimiento intensivo y continuo de los Ecosistemas Forestales. Red de Nivel II. Memoria 2008. Parcela 44 Qf (Toledo). Dirección General del Medio Natural, Ministerio de Medio Ambiente, Medio Rural y Marino. Online [URL] http://www.magrama.gob.es/es/biodiversidad/temas/ sanidad-forestal/redes-de-seguimiento-de-los-bosques/index redes_seguimiento_bosques.aspx (Accessed on 2 April 2013)

Massa, B., F. Lo Valvo, B. Margagliotta \& M. Lo Valvo, 2004. Adaptive plasticity of blue tits (Parus caeruleus) and great tits (Parus major) breeding in natural and semi-natural insular habitats. Italian Journal of Zoology, 71: 209-217.

Minot, E. O., 1981. Effects of interspecific competition for food in breeding blue and great tits. Journal of Animal Ecology, 50: $375-385$.
Moreno, E. \& L. M. Carrascal, 1993. Leg morphology and feeding postures in four Parus species: An experimental ecomorphological approach. Ecology, 74: 2037-2044.

Murakami, M., 1999. Effect of avian predation on survival of leaf-rolling lepidopterous larvae. Researches on Population Ecology, 41: 135-138.

Naef-Daenzer, B. \& L. F. Keller, 1999. The foraging performance of great and blue tits Parus major and P. caeruleus in relation to caterpillar development and its consequences for nestling growth and fledging weight. Journal of Animal Ecology, 68: 708-718.

Naef-Daenzer, L., B. Naef-Daenzer \& R. G. Nager, 2000. Prey selection and foraging performance of breeding great tits Parus major in relation to food availability. Journal of Avian Biology, 31: 206-214.

Notario, A., L. Castresana, J. Cifuentes, A. Expósito \& A. Vives Moreno, 2007. Contribución a la elaboración del Catálogo Sistemático de los Lepidoptera presentes en el Monte Quintos de Mora en Los Yébenes (Toledo, España). Investigación Agraria: Sistemas y Recursos Forestales, 16: 197-203.

Nour, N., D. Currie, E. Matthysen, R. Van Damme \& A. A. Dhondt, 1998. Effects of habitat fragmentation on provisioning rates, diet and breeding success in two species of tit (great tit and blue tit). Oecologia, 114: 522-530.

Pagani-Núñez, E., I. Ruiz, J. Quesada, J. J. Negro \& J. C. Senar, 2012. The diet of Great tit Parus major nestlings in a Mediterranean Iberian forest: The important role of spiders. Animal Biodiversity and Conservation, 34: 355-361.

Perrins, C. M., 1991. Tits and their caterpillar food supply. Ibis, 133: 49-54.

Pimentel, C. \& J. A. Nilsson, 2007. Response of great tits Parus major to an irruption of a pine processionary moth Thaumetopoea pityocampa population with a shifted phenology. Ardea, 95: 191-199.

Pimentel, C. \& J. A. Nilsson, 2009. Response of passerine birds to an irruption of a pine processionary moth Thaumetopoea pityocampa population with a shifted phenology. Ardeola, 56: 189-203.

Przybylo, R., 1995. Intersexual niche differentiation: Field data on the Great tit (Parus major). Journal of Avian Biology, 26: $20-24$.

Przybylo, R. \& J. Merilä, 2000. Intersexual niche differentiation in the blue tit (Parus caeruleus). Biological Journal of the Linnean Society, 69: 233-244.

Radford, A. N., 2008. Age-related changes in nestling diet of the cooperatively breeding green woodhoopoe. Ethology, 114: 907-915.

Ramsay, S. L. \& D. C. Houston, 2003. Amino acid composition of some woodland arthropods and its implications for breeding tits and other passerines. Ibis, 145: 227-232.

Royama, T., 1970. Factors governing the hunting behaviour and selection of food by the great tit. Journal of Animal Ecology, 39: 619-668

Sanz, J. J., V. García-Navas \& J. V. Ruiz-Peinado, 2010. Effect of habitat type and nest-site characteristics on the breeding performance of Great and Blue Tits (Parus major and $P$. caeruleus) in a Mediterranean landscape. Ornis Fennica, 87: 41-51.

Searcy, W., S. Peters \& S. Nowicki, 2004. Effects of early nutrition on growth rate and adult size in song sparrows Melospiza melodia. Journal of Avian Biology, 33: 269-279. 
Soma, M., M. Takahasi, M. Ikebuchi, H. Yamada, M. Suzuki, T. Hasegawa \& K. Okanoya, 2006. Early rearing conditions affect the development of body size and song in Bengalese finches. Ethology, 112: 1071-1078.

Soria, S., 1987. Lepidópteros defoliadores de Quercus pyrenaica Willdenow, 1805. Boletín de Sanidad Vegetal. Fuera de serie No 7. Ministerio de Agricultura, Pesca y Alimentacion, Madrid.

Tilgar, V., R. Mänd, P. Kilgas \& S. J. Reynolds, 2005. Chick development in free-living great tits Parus major in relation to calcium availability and egg composition. Physiological and Biochemical Zoology, 78: 590-598.

Török, J., 1985. The diet niche relationships of the great tit (Parus major) and the blue tit (P. caeruleus) nestlings in an oak forest. Opuscula Zoologica, 19-20: 99-108.

Török, J., 1986. Food segregation in three hole-nesting bird species during the breeding season. Ardea, 74: 129-136.

Török, J. \& L. Tóth, 1999. Asymmetric competition between two tit species: A reciprocal removal experiment. Journal of Animal Ecology, 68: 338-345.
Tremblay, I., D. Thomas, J. Blondel, P. Perret \& M. M. Lambrechts, 2005. The effect of habitat quality on foraging patterns, provisioning rate and nestling growth in Corsican Blue Tits Parus caeruleus. Ibis, 147: 17-24.

Tutin, T. G., N. A. Burges, A. O. Chater, J. R. Edmonson, V. H. Heywood, D. M. Moore, D. H. Valentine, S. M. Walters \& D. A. Webb, 1993. Flora europaea I. $2^{\text {nd }}$ Edition. Cambridge University Press.

Veen, T., B. C. Sheldon, F. J. Weissing, M. E. Visser, A. Qvarnström \& G.-P. Sætre, 2010. Temporal differences in food abundance promote coexistence between two congeneric passerines. Oecologia, 162: 873-884.

Visser, M. E. \& C. Both, 2005. Shifts in phenology due to global climate change: The need for a yardstick. Proceedings of the Royal Society of London B, 272: 2561-2569.

Wilkin, T. A., L. E. King \& B. C. Sheldon, 2009. Habitat quality, nestling diet, and provisioning behaviour in great tits Parus major. Journal of Avian Biology, 40: 135-145.

Wright, J., C. Both, P. A. Cotton \& D. Bryant, 1998. Quality vs quantity: Energetic and nutritional tradeoffs in parental provisioning strategies. Journal of Animal Ecology, 67: 620-634. 